\title{
APLIKASI ANALISIS KELAS LATEN UNTUK MENDETEKSI KARAKTERISTIK UNIK PADA KONSTRUK EFIKASI GURU DALAM MENGAJAR
}

\author{
Wabyu Widhiarso ${ }^{*}$, M. Noor Rochman Hadjam ${ }^{1}$ \\ ${ }^{1}$ Fakultas Psikologi Universitas Gadjah Mada \\ ${ }^{1}$ Jl. Sosio Humaniora Bulaksumur, Karang Malang, Caturtunggal, Depok, Sleman 55281, \\ Yogyakarta, Indonesia \\ * Corresponding Author. Email: wahyu_psy@ugm.ac.id
}

\begin{abstract}
Abstrak
Penelitian ini bertujuan untuk mengidentifikasi adanya kelompok-kelompok unik berdasarkan atribut yang terukur pada efikasi mengajar guru untuk memunculkan tipe-tipe unik efikasi guru. Penelitian ini melibatkan 142 guru yang diminta mengisi Skala Efikasi Mengajar. Analisis kelas laten yang dilakukan memunculkan empat tipe guru berdasarkan responsnya. Dua kelas menunjukkan tipe kategori yang berjenjang (efikasi tinggi dan rendah) dan dua kelas menunjukkan kategori unik (efikasi terkait dengan interaksi dengan siswa dan terkait dengan persiapan mengajar). Adanya dua kelas unik tersebut menunjukkan bahwa dimensi-dimensi efikasi guru dalam mengajar tidak bersifat homogen. Ada guru yang dominan pada satu dimensi akan tetapi tidak dominan pada dimensi lainnya. Adanya guru dengan karakteristik unik ini memberikan konsekuensi agar penyusunan alat ukur efikasi diri dan program-program peningkatan efikasi guru dalam mengajar dapat mengakomodasinya.
\end{abstract}

Kata kunci: efikasi guru dalam mengajar, analisis kelas laten, kategori unik

\section{THE APPLICATION OF LATENT CLASS ANALYSIS TO DETECT THE UNIQUE CHARACTERISTICS ON TEACHERS EFFICACY CONSTRUCTS IN TEACHING}

\begin{abstract}
This study aims to identify the unique groups based on attributes measured on the efficacy of teachers to bring unique types of teacher efficacy. The research involved a total of 142 teachers who were asked to complete Teaching Efficacy Scale. The results of latent class analysis exhibit four types of teacher's efficacy based on their similarity responses to given measure. Two classes show an ordered category (high efficacy and low teaching category) whereas two classes show a unique category (efficacy related to interaction with students and efficacy related to teaching preparation). The presence of these two unique classes suggests that teacher perceptions of his/her ability in teaching can be viewed as a type of attribute. There are teachers swho have high levels of efficacy in one dimension but tend to be low on other dimensions. The presence of this type has several consequences for the development of teaching efficacy measure, and programs to improve teachers should accommodate this unique type.
\end{abstract}

Keywords: teaching efficacy, latent class analysis, unique categories

Permalink/DOI: bttp://dx.doi.org/10.21831/pep.v20i2.7698 


\section{Pendahuluan}

Efikasi guru dalam mengajar memegang peranan penting dalam kesuksesan dan keberhasilan siswa dalam belajar. Penelitian menunjukkan bahwa efikasi diri berpengaruh terhadap peningkatan kinerja individu dan cara mereka mengatasi tugas-tugas yang dihadapi (Magogwe, 2006). Hasil penelitian lainnya menunjukkan bahwa efikasi dalam mengajar mempengaruhi performansi guru yang positif, misalnya ketekunan mengerjakan tugas, keberanian mengambil risiko, dan penggunaan inovasi pembelajaran (Ashton, Webb, \& Nancy, 1982), penetapan tujuan yang optimal dan efektivitas mengajar, persepsi terhadap peluang dan hambatan, sikap positif terhadap kemampuan siswa (Gibson \& Dembo, 1984). Penelitian lainnya menunjukkan bahwa efikasi mengajar guru mempengaruhi gaya komunikasi guru (Flores \& Clark, 2004), motivasi, optimalisasi kognisi dan emosi guru ketika mengajar (Matthews, Deary, \& Whiteman, 2003), dan kesabaran guru ketika menghadapi siswa yang bermasalah (Woolfolk, Rosoff, \& Hoy, 1990). Selain pengetahuan yang telah dimiliki, guru yang memiliki efikasi yang tinggi lebih terbuka dan mengadopsi praktik-praktik baru dalam proses pembelajaran. Penelitian Ball (1990) menunjukkan bahwa keyakinan guru tentang pelajaran matematika dan ilmu pengetahuan mempengaruhi cara mereka mengajar.

Konstruk efikasi guru dalam mengajar diperkenalkan oleh Albert Bandura yang diartikan sebagai keyakinan guru bahwa mereka mampu memfasilitasi bagaimana siswa belajar dengan baik meski mereka mengalami kesulitan dan kurang termotivasi (Bandura, 1977). Efikasi guru dalam mengajar juga didefinisikan sebagai penilaian guru terhadap kemampuannya untuk mewujudkan hasil yang diinginkan terkait dengan keterlibatan siswa dalam belajar (TschannenMoran \& Hoy, 2001). Dalam ulasannya, Jerald (2007) menyoroti beberapa perilaku guru yang terkait dengan efikasi diri. Guru yang memiliki efikasi tinggi ditandai dengan: (a) cenderung memfokuskan pada kegiatan perencanaan dan pengorganisasian; (b) lebih terbuka terhadap ide-ide baru dan lebih bersedia untuk bereksperimen dengan metode baru untuk lebih memenuhi kebutuhan siswa; (c) tetap gigih dan tangguh ketika apa yang dilakukan tidak berjalan lancar; (d) menghindari kritik terhadap siswa yang membuat kesalahan; dan (e) menemani siswa yang mengalami kesulitan.

Efikasi mengajar guru merupakan konsep multidimensi (Pang, 2009). Pandangan dua dimensi melihat ada dua jenis keyakinan yang membentuk konstruk efikasi diri. Pertama, efikasi mengajar yang berkaitan kepercayaan diri guru terhadap kemampuan mereka dalam mengajar. Kedua, efikasi secara umum yang memuat keyakinan guru terhadap efektivitas pembelajaran untuk mengakomodasi siswa yang mengalami kesulitan (Hoy, 2000). Para peneliti juga menemukan bahwa dua jenis keyakinan tersebut bersifat independen. Adanya independensi konstruk ini mendukung bahwa guru yang percaya diri mampu mengajar dengan efektif belum tentu yakin bahwa pembelajaran yang dilakukan dapat mengakomodasi siswa yang memiliki kesulitan belajar.

Pandangan empat dimensi membagi efikasi guru dalam mengajar terdiri dari: dimensi pertama yang merujuk pada sistem kepercayaan guru secara umum mengenai tindakan yang mereka lakukan dan hasil yang akan mereka dapatkan; dimensi kedua yang merujuk pada persepsi keyakinan secara umum; dimensi ketiga yang merujuk pada atribut yang lebih spesifik yaitu keyakinan guru untuk memotivasi siswa; dan dimensi keempat adalah sistem kepercayaan spesifik tentang kompetensi pribadi dalam memotivasi siswa (Ashton, Webb, \& Nancy, 1982). Efikasi guru juga dapat dibagi menjadi tujuh dimensi yang meliputi: (a) perencanaan jangka panjang, (b) pengelolaan lingkungan belajar, (c) iklim kelas, (d) peningkatan proses pembelajaran, (e) stimulasi siswa dalam berpikir, (f) pengelolaan kelas berbasis asesmen terhadap belajar siswa (classroom-basedassessment of studentlearning), dan ( $\mathrm{g}$ ) tanggung jawab profesional (Dellinger, Bobbet, Olivier, \& Ellett, 2008). 
Konsep efikasi yang bersifat multidimensi ini berpotensi menyebabkan efikasi guru mengajar menjadi sebuah konstruk yang bersifat kategorikal. Efikasi guru sulit untuk dilihat sebagai atribut kontinum yang bergerak dari rendah hingga tinggi karena setiap dimensi berdiri sendiri. Di sisi lain banyaknya faktor yang mempengaruhi efikasi guru mempengaruhi dimensi-dimensi yang di dalam pengukuran efikasi mengajar berpotensi memunculkan kategori guru yang bersifat unik. Misalnya ada guru yang tinggi dalam hal efikasi terhadap perencanaan akan tetapi rendah dalam hal implementasi. Sejumlah penelitian menemukan beberapa faktor yang mempengaruhi efikasi guru dalam mengajar. Misalnya tingkat pendidikan (Leyser, 2002), pengalaman mengajar (Wilson \& Tan, 2004), kepemimpinan kepala sekolah (Ryan, 2007), pembagian otoritas dalam pengambilan keputusan (Dodgshon, 2002) dan faktor demografik (Franklin, 1989). Faktor-faktor ini meningkatkan potensi pengukuran terhadap efikasi akan menghasilkan skor yang memuat beberapa atribut atau dimensi ukur. Sifat skor yang multidimensi ini tidak hanya menjelaskan heterogenitas butir-butir alat ukur yang menghasilkan skor tersebut akan tetapi heterogenitas subjek yang menjadi target ukur tes ini juga dapat mengakibatkannya. Jika heterogenitas butir dikaji melalui analisis faktor, heterogenitas subjek dikaji melalui analisis kelas laten.

Dalam teori pengukuran, kategori yang tidak menunjukkan jenjang dinamakan dengan kategori yang bersifat eksklusif (unik) dan menunjukkan sebuah tipologi (Hofstee, 2003). Jika diterapkan pada konstruk efikasi guru maka adanya tipologi ini menyebabkan konstruk efikasi guru dalam mengajar tidak hanya terkategorikan berdasarkan kategori berjenjang yang bersifat vertikal (tinggi-rendah) saja melainkan juga kategori tipologi yang bersifat horizontal (tipe A-tipe B). Kategori-kategori tipologi ini berpotensi muncul jika suatu suatu konstruk ukur merepresentasi-kan atribut-atribut yang sifatnya kompleks. Efikasi guru merepresentasikan kemampuan guru yang kompleks dan multidimensi karena ada beragam indikator perilaku yang memanifestasikannya. Potensi adanya kategori yang bersifat unik di dalam konstruk efikasi guru ini juga disadari oleh peneliti lain (Eddy \& Easton-Brooks, 2011). Mereka melihat bahwa selama ini efikasi guru dilihat sebagai atribut guru yang memuat indikator-indikator yang homogen satu dengan lainnya padahal sebenarnya memuat indikator-indikator yang heterogen. Jika konstruk efikasi guru dilihat sebagai konstruk yang memuat indikator-indikator homogen, maka kategorisasi skor guru hanya berupa jenjang tinggi rendah. Jika konstruk efikasi guru dilihat sebagai konstruk multidimensi, maka akan ada dua jenis kategorisasi yang dihasilkan. Pertama adalah kategorisasi jenjang (tinggirendah) dan kedua adalah kategorisasi tipologi (tipe efikasi A-tipe efikasi B). Penelitian ini berangkat dari asumsi bahwa kategorisasi skor efikasi guru akan menghasilkan dua jenis kategorisasi tersebut karena secara teoretik konstruk efikasi merupakan konstruk yang multidimensional.

Sebelum ditemukannya teknik analisis yang mengakomodasi adanya kelompok-kelompok unik dalam sampel, banyak penelitian yang melihat efikasi guru dalam mengajar sebagai konstruk yang kontinum, meski mereka mendefinisikannya sebagai konstruk multidimensi. Ashton, Webb, \& Nancy (1982) mengategorikan efikasi guru mengajar dalam kategori rendah dan tinggi. Guru yang memiliki efikasi rendah cenderung: (a) melihat siswa yang mengalami kesulitan belajar sebagai ancaman terhadap pengondisian kelas yang kondusif dalam belajar, (b) memandang perilaku siswa selalu berpotensi menimbulkan gangguan dan (c) memperlakukan siswa yang pandai secara istimewa. Kecenderungan ini merupakan representasi dari ketidakyakinan guru terhadap kemampuannya dalam mengelola siswa dan kelas. Di sisi lain, guru yang memiliki efikasi tinggi akan: (a) memiliki harapan yang jelas pada setiap pertemuannya dengan siswa di kelas, (b) konsisten dalam merealisasikan harapan tersebut, (c) memiliki kesadaran terhadap semua hal yang terjadi di dalam kelas, dan 
(d) cenderung mendorong siswa untuk berkonsentrasi pada tugas mereka.

Penelitian-penelitian terbaru mulai mengeksplorasi kelompok, klaster, atau kelas yang menunjukkan tipe efikasi guru. Misalnya penelitian Buss (2010) yang mengidentifikasi klaster-klaster efikasi guru dari lima dimensi efikasi guru dalam mengajar yaitu ilmu pengetahuan, matematika, membaca, manajemen kelas, dan instruksi umum. Hasil pengelompokan yang dilakukan menemukan bahwa secara keseluruhan efikasi guru terhadap penguasaan ilmu pengetahuan dan matematika lebih rendah dibandingkan dengan efikasi terkait dengan proses mengajar. Hasil penelitian ini menunjukkan bahwa banyak guru yang merasa pengetahuan yang mereka miliki belum memadai yang mengakibatkan mereka tidak yakin mampu menyelenggarakan proses pembelajaran dengan efektif. Dari perbandingan kedua penelitian tersebut dapat disimpulkan bahwa perspektif yang melihat efikasi mengajar sebagai konstruk yang kontinum memiliki keterbatasan karena tidak memberikan informasi adanya guru yang memiliki guru yang memiliki karakteristik efikasi mengajar yang unik seperti yang diungkap oleh Buss(2010).

Eksplorasi lebih lanjut mengenai tipetipe efikasi guru dalam mengajar sangat diperlukan agar memberikan gambaran lebih komprehensif untuk mengenai efikasi guru di lapangan. Hasil eksplorasi keberadaan karakteristik efikasi guru yang unik memiliki beberapa manfaat. Pertama, pemahaman adanya karakteristik unik tersebut dapat memberikan masukan mengenai instrumen pengukuran efikasi guru. Instrumen pengukuran yang tidak mewadahi heterogenitas karakteristik unik sampel ini akan menghasilkan informasi yang bias (Valentini, Di Battista, \& Antonio Gattone, 2011). Hasil pengukuran akan menghasilkan mana guru yang memiliki kemampuan rendah atau tinggi yang didapatkan dari skor total instrumen. Jika dieksplorasi lebih lanjut, guru-guru yang dikategorikan berkemampuan rendah belum tentu rendah dalam semua indikator ukur. Dapat saja terjadi, rendah pada beberapa indikator ukur akan tetapi tinggi pada indi- kator ukur lainnya. Kedua, mengenali adanya karakteristik unik ini akan membantu para pengambil kebijakan di dunia pendidikan dalam pengembangan sumber daya manusia. Selain pelatihan-pelatihan yang bersifat umum, yaitu pelatihan yang menjangkau keseluruhan kemampuan yang diperlukan oleh guru, pelatihan yang lebih khusus juga perlu dilakukan. Sasarannya adalah kemampuan spesifik guru yang memerlukan peningkatan lebih lanjut. Untuk mengetahui dimensi mana yang memerlukan peningkatan lebih lanjut maka pemahaman mengenai karakteristik unik guru sangat diperlukan.

Untuk mengidentifikasi adanya kelompok-kelompok unik berdasarkan atribut yang diukur diperlukan teknik analisis yang mampu mengakomodasinya. Salah satu teknik yang dapat mengakomodasi tujuan ini adalah analisis kelas laten. Analisis kelas laten memiliki kesamaan dengan analisis faktor eksploratori. Jika analisis faktor bertujuan untuk mengidentifikasi butir-butir yang memiliki kesamaan dalam mengukur konstruk ukur, maka analisis kelas laten bertujuan untuk mengidentifikasi individu berdasarkan kesamaannya dalam menanggapi butirbutir dalam instrumen pengukuran. Analisis kelas laten adalah salah satu dari beberapa teknik pereduksian data menjadi bagianbagian (Nylund, Asparouhov, \& Muthén, 2007).

Kelompok-kelompok individu yang dihasilkan dari analisis dinamakan dengan kelas. Kelas yang dihasilkan dinamakan dengan kelas laten karena kelas-kelas tersebut didapatkan dari penyimpulan terhadap kesamaan respons individu. Nama kelas diberikan berdasarkan interpretasi terhadap kesamaan pola respons tersebut. Berdasarkan uraian teoretik tersebut dapat disimpulkan bahwa konstruk efikasi guru berpotensi menjelaskan dua kategori, yaitu kategori jenjang dan kategori tipologi. Penelitian ini mengeksplorasi keberadaan kedua jenjang tersebut melalui analisis kelas laten. Terkait dengan hal tersebut, penelitian ini bertujuan untuk mengidentifikasi adanya kelompokkelompok unik berdasarkan atribut yang 
terukur pada efikasi mengajar guru untuk memunculkan tipe-tipe unik efikasi guru.

\section{Metode}

Partisipan dari penelitian ini adalah guru berprestasi yang mewakili semua provinsi di Indonesia yang berjumlah 142 orang dengan jumlah 65 orang $(46 \%)$ adalah pria dan 77 orang $(54 \%)$ adalah wanita. Usia partisipan bergerak dari 24 hingga 57 tahun dengan rerata usia 41,23 tahun. Partisipan adalah guru tetap di sekolahnya yang mengajar mata pelajaran yang bervariasi. Lokasi sekolah tempat mereka mengajar bervariasi antara sekolah di kota dan di luar perkotaan. Pengambilan sampel dilakukan ketika para partisipan mengikuti acara lokakarya yang diadakan di Jakarta yang diselenggarakan oleh Depdiknas Jakarta. Peneliti menjelaskan bahwa kegiatan pengambilan data ini tidak akan mempengaruhi penilaian terhadap partisipan dan menekankan bahwa anonimitas partisipan tetap terjaga. Semua partisipan telah mengisi informconsent sebelum mereka mengisi kuesioner yang dibagikan.

Efikasi guru dalam mengajar diukur dengan menggunakan Skala Efikasi Mengajar yang dikembangkan oleh peneliti berdasarkan teori yang dikembangkan oleh Newman (1999) mengenai kegiatan rutin guru dalam mengajar. Dimensi efikasi mengajar yang diakomodasi dalam instrumen ini adalah perencanaan, implementasi dan evaluasi guru dalam mengajar. Dimensi tersebut menekankan pada pengelolaan kelas yang merupakan aktivitas guru sehari-hari dan dijabarkan menjadi tiga subskala. Ketiga subskala tersebut adalah: (a) faktor perencanaan mengajar yang mengukur seberapa jauh guru mampu mempersiapkan proses mengajar yang efektif misalnya penguasaan kurikulum secara komprehensif (butir 1) dan penyusunan silabus yang sistematis (butir 3), (b) faktor pelaksanaan mengajar yang mengukur efikasi guru dalam mengajar secara efektif yang ditunjukkan misalnya melalui penggunaan metode dan media mengajar yang inovatif (butir 4) atau pendekatan kepada siswa yang mengalami hambatan belajar (butir 6), (c) faktor evaluasi mengajar yang mengukur efikasi guru dalam mengukur hasil belajar siswa yang ditunjukkan dengan misalnya melalui aplikasi variasi pengukuran dan evaluasi hasil belajar (butir 10) dan penyusunan instrumen pengukuran hasil belajar siswa yang valid dan reliabel (butir 11). Instrumen ini memuat 12 butir pernyataan yang berbentuk Skala Likert dengan 5 alternatif respon yang bergerak dari sangat yakin hingga sangat tidak yakin yang diskor 1 sampai 5 . Reliabilitas instrumen ini diestimasi dengan menggunakan teknik konsistensi internal melalui nilai alpha Cronbach menghasilkan 0,79 (faktor persiapan); 0,84 (faktor pelaksanaan); dan 0,83 (faktor evaluasi belajar).

Tahap-tahap yang dilakukan untuk menganalisis data adalah sebagai berikut.

Pertama adalah mengidentifikasi jumlah kelas. Pada tahap ini berbagai model dengan jumlah kelas yang berbeda (2 hingga 4 kelas) dipakai untuk memodelkan data. Setiap model akan menghasilkan kriteria informasi yang menunjukkan ketepatan model dengan data. Penelitian ini menggunakan kriteria informasi Akaike dan Bayesian (AIC dan BIC) sebagai dasar untuk menentukan model yang tepat karena kriteria ini mengakomodasi ukuran sampel dan menghindari parameterisasi yang berlebih.

Kedua adalah mengidentifikasi profil tiap kelas. Setelah jumlah kelas ditentukan, tahap selanjutnya adalah menjabarkan profil dan membandingkan kekhasan setiap kelas berdasarkan profil probabilitas untuk mendapatkan skor butir yang tinggi.

Untuk menyederhanakan interpretasi hasil analisis, data skor skala yang bersifat dikotomi di transformasi menjadi data dikotomi. Skor butir 1 hingga 3 ditransformasi menjadi 0 sedangkan skor butir 4 dan 5 ditransformasi menjadi 1. Prosedur ini telah banyak dipakai oleh penelitian karena skor hasil transformasi berkorelasi tinggi dengan skor sebelum transformasi. Analisis data dilakukan dengan bantuan program MPLUS (Muthen \& Muthen, 2005). 


\section{Hasil dan Pembahasan}

\section{Perbandingan Antarmodel}

Berdasarkan hasil perbandingan antara model dari model 2 kelas hingga 5 kelas didapatkan bahwa efikasi guru dalam mengajar lebih tepat dibagi menjadi 4 kelas. Kesimpulan ini diambil berdasarkan selisih nilai AIC dari model 4 dan 5 kelas tidak cukup besar dibanding dengan selisih model 1 dan 2 kelas serta model 3 dan 4 kelas. Hasil yang setara juga ditunjukkan oleh nilai BIC terjustifikasi (ABIC). Sebaliknya, nilai BIC menunjukkan pola perubahan yang tidak konsisten. Dari perbandingan nilai entropi yang menunjukkan ketepatan model dengan data dapat diketahui bahwa nilai entropi terbesar ditunjukkan oleh Model 4 kelas. Hasil selengkapnya dapat dilihat pada Tabel 1.

Tabel 1. Perbandingan Indeks Ketepatan Model Berdasarkan Jumlah Kelas

\begin{tabular}{|c|c|c|c|c|}
\hline $\begin{array}{l}\text { Indeks } \\
\text { Ketepatan }\end{array}$ & Model & Model & Model & Model \\
\hline atcat & 2 Kelas & 3 Kelas & & \\
\hline AIC & 1515.35 & 1441.77 & 1409.58 & 1409.12 \\
\hline BIC & 1589.24 & 1554.09 & 1560.32 & 1598.29 \\
\hline ABIC & 1510.14 & 1433.85 & 1398.96 & 1395.79 \\
\hline Entropi & 0.92 & 0.94 & 0.97 & 0.95 \\
\hline
\end{tabular}

Proporsi Keanggotaan Kelas

Sesuai dengan prosedur analisis data, setelah model pembagian empat kelas ditetapkan lebih mewakili data dibanding dengan model lainnya maka langkah selanjutnya adalah mengidentifikasi profil keempat kelas tersebut. Tabel 2 menunjukkan jumlah guru yang masuk dalam setiap kelas. Jumlah kelas terbanyak adalah Kelas-2 (53 persen) dan jumlah terkecil adalah Kelas-4 ( 9 persen). Analisis kelas laten menggunakan pendekatan peluang. Dengan pendekatan ini setiap guru memiliki peluang untuk masuk pada tiap-tiap kelas. Untuk menentukan seorang guru masuk ke dalam kelas apa ditentukan oleh nilai peluang yang paling besar. Tabel 2 menunjukkan bahwa guru yang masuk ke dalam Kelas-1 rata-rata memiliki peluang sebesar 99 persen untuk masuk ke dalam Kelas-1. Sementara itu, peluang untuk masuk ke dalam kelas lain cukup kecil karena di bawah 1 persen. Pola yang sama juga ditunjukkan oleh kelas yang lain. Peluang untuk masuk ke dalam kelas yang sudah ditetapkan lebih tinggi dibanding dengan kelas lainnya. Oleh karena itu, dapat disimpulkan bahwa pembagian menjadi empat kelas cukup optimal dalam membedakan guru berdasarkan karakteristik efikasi mengajarnya.

Tabel 2. Proporsi Anggota Kelas dan Probabilitas Keanggotaan

\begin{tabular}{ccccccc}
\hline & & \multicolumn{5}{c}{ Rerata Persentase Masuk } \\
Kelas Frekuensi & $\%$ & \multicolumn{4}{c}{ dalam Kelas } \\
\cline { 3 - 7 } & & 1 & 2 & 3 & 4 \\
\hline I & 17 & $12 \%$ & 0,99 & 0,01 & 0,01 & 0,00 \\
II & 75 & $53 \%$ & 0,00 & 0,98 & 0,02 & 0,00 \\
III & 37 & $26 \%$ & 0,00 & 0,00 & 1,00 & 0,00 \\
IV & 13 & $9 \%$ & 0,00 & 0,02 & 0,02 & 0,96 \\
\hline
\end{tabular}

Profil Masing-Masing Kelas

Melalui analisis kelas laten, guru dimasukkan dalam kelas-kelas berdasarkan kesamaan karakteristik efikasi mengajar mereka. Kesamaan tersebut dilihat dari respons yang mereka berikan terhadap instrumen pengukuran. Tabel 3 menunjukkan profil setiap kelas berdasarkan probabilitas untuk memiliki indikator efikasi mengajar. Tabel tersebut menunjukkan bahwa guru yang masuk ke dalam Kelas-1 adalah guru yang memiliki efikasi mengajar yang tinggi. Nilai peluang guru pada kelas ini semuanya berada di atas 0,5. Sebaliknya, guru yang masuk dalam Kelas-2 adalah guru yang memiliki nilai peluang di bawah 0,5 untuk semua indikator. Oleh karena itu, kelas ini dinamakan dengan Kelas efikasi mengajar yang rendah. 
Tabel 3. Profil setiap Kelas

\begin{tabular}{llllll}
\hline \multirow{2}{*}{ Butir } & \multicolumn{1}{c}{ Indikator } & \multicolumn{3}{c}{ Kelas } \\
& & I & II & III & IV \\
\hline ef-01 & Menguasai materi secara komprehensif & + & - & - & + \\
ef-02 & Merencanakan proses mengajar dengan efektif & + & - & - & + \\
ef-03 & Menyusun silabus yang sistematis & + & - & - & + \\
ef-04 & Menggunakan metode mengajar inovatif & + & - & - & + \\
ef-05 & Menguasai variasi media mengajar & + & - & - & + \\
ef-06 & Merangsang siswa aktif belajar & + & - & + & + \\
ef-07 & Pendekatan pada siswa yang mengalami kesulitan belajar & + & - & + & - \\
ef-08 & Mengkaitkan materi belajar dengan konteks & + & - & + & - \\
ef-09 & Menguasai strategi pengukuran kompetensi siswa & + & - & - & - \\
ef-10 & Mengaplikasikan variasi teknik evaluasi hasil belajar & + & - & - & - \\
ef-11 & Menyusun instrumen pengukuran yang valid dan reliabel & + & - & - & - \\
ef-12 & Memberikan umpan balik yang tepat kepada siswa & + & - & + & - \\
\hline
\end{tabular}

Guru yang masuk dalam Kelas 3 dan Kelas-4 memiliki keunikan. Pada beberapa indikator mereka bisa menguasainya (peluang di atas 0,5) namun pada indikator yang lain mereka tidak menguasainya (peluang di bawah 0,5). Berdasarkan indikator yang bisa dikuasai maka Kelas-1 dinamakan Kelas efikasi peduli. Guru-guru pada kelas ini sangat peduli dengan siswanya yang terlihat dari tingginya indikator pelayanan kepada siswa, dari menyemangati hingga memberikan umpan balik terhadap siswa. Sementara itu, guru dengan profil Kelas-4 dinamakan dengan Kelas efikasi perencana. Guruguru ini memiliki indikator pada level tinggi hanya pada hal-hal terkait dengan perencanaan mengajar dan penguasaan media serta materi untuk mengajar.

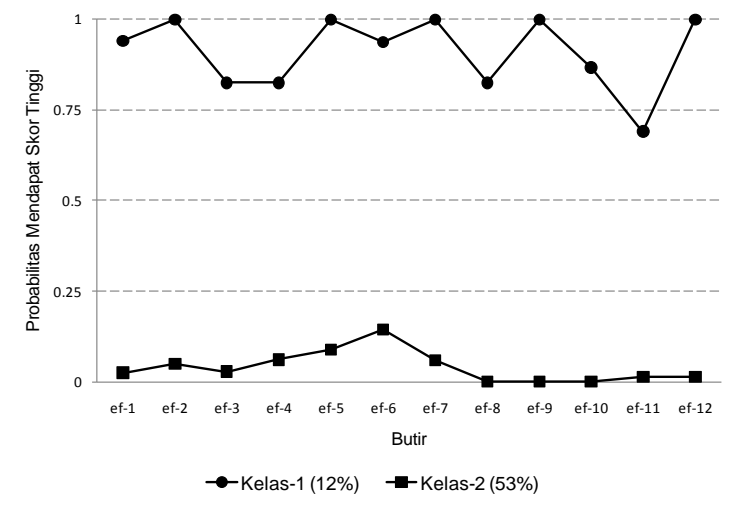

Gambar 1. Profil Kelas-1 dan Kelas-2

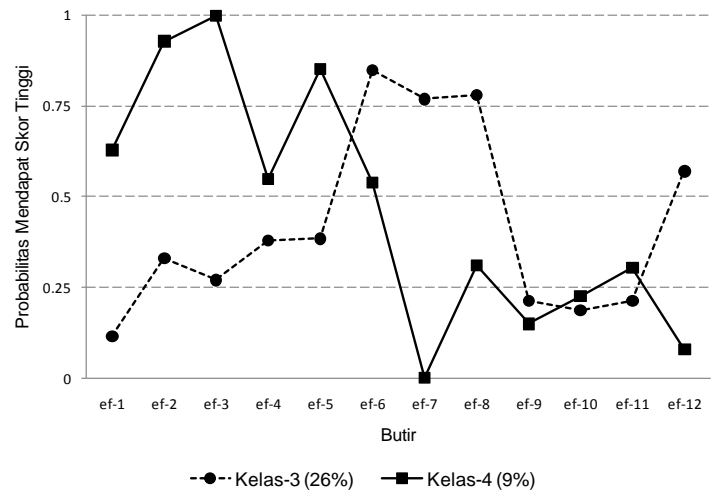

Gambar 2. Profil Kelas-2 dan Kelas-4

Profil keempat kelas secara visual dapat dilihat pada Gambar 1 dan 2. Sumbu-X pada gambar tersebut menunjukkan peluang guru untuk memiliki indikator efikasi mengajar yang diukur sedangkan sumbu-Y menjelaskan butir yang mengukur indikator efikasi mengajar. Gambar 1 menampilkan profil Kelas-1 dan Kelas-2. Kedua kelas ini menunjukkan kategori berjenjang atau kategori yang menunjukkan level kategori rendah dan tinggi. Gambar 2 menampilkan profil Kelas-3 dan Kelas-4 yang merupakan kategori yang bersifat unik. Pada indikator tertentu mereka memiliki peluang besar tetapi pada kategori lainnya memiliki peluang yang kecil. Secara umum penelitian ini mendukung hipotesis yang diajukan mengenai keberadaan guru dengan tipe efikasi meng- 
ajar yang unik dan tidak menunjukkan tipe berdasarkan kategori berjenjang.

Tinjauan Tipe Berdasarkan Data Demografi

Tabel 4 menjelaskan perbedaan setiap kelas berdasarkan tiga data demografi, yaitu jenis kelamin, usia dan masa kerja. Berdasarkan perbandingan antardata demografi tidak didapatkan perbedaan yang signifikan. Uji kai-kuadrat menunjukkan tidak ada perbedaan profil kelas ditinjau dari jenis kela$\min \left(\chi^{2}=4,55 ; p>0,05\right)$ dan uji analisis varians satu jalur juga tidak menemukan perbedaan yang signifikan $F=1,42 ; p>0,05$ dan $\mathrm{F}=1,93 ; \mathrm{p}>0,05)$.

Tabel 4. Profil Kelas Ditinjau dari Data Demografi

\begin{tabular}{ccccccc}
\hline \multirow{2}{*}{ Kelas } & \multicolumn{2}{c}{ Jenis Kelamin } & \multicolumn{2}{c}{ Usia } & \multicolumn{2}{c}{ Masa Kerja } \\
\cline { 2 - 7 } & Pria & Wanita & Rerata & SD & Rerata & SD \\
\hline I & $3 \%$ & $9 \%$ & 41.53 & 7.21 & 16.24 & 7.22 \\
II & $5 \%$ & $4 \%$ & 40.46 & 5.19 & 14.69 & 5.45 \\
III & $11 \%$ & $15 \%$ & 41.54 & 5.13 & 15.76 & 5.36 \\
IV & $27 \%$ & $26 \%$ & 41.15 & 5.45 & 15.77 & 5.44 \\
\hline Statis & $\chi^{2}=4,55$ & \multicolumn{2}{c}{$\mathrm{F}=1,42$} & \multicolumn{2}{c}{$\mathrm{F}=1,93$} \\
-tik & $(\mathrm{p}>0,05)$ & $(\mathrm{p}>0,05)$ & $(\mathrm{p}>0,05)$ \\
\hline
\end{tabular}

Diskusi

Adanya kelompok guru dengan karakteristik efikasi mengajar yang unik ini mendukung pandangan para ahli yang melihat bahwa efikasi merupakan konstruk yang multidimensional. Penelitian ini mendukung hipotesis yang diajukan mengenai keberadaan guru dengan tipe efikasi mengajar yang unik dan tidak menunjukkan tipe berdasarkan kategori berjenjang. Adanya dua kelompok unik guru yang diidentifikasi dalam penelitian ini yaitu efikasi mengajar yang terkait interaksi guru pada siswa dan efikasi yang terkait dengan perencanaan. Efikasi mengajar terkait dengan interaksi guru merupakan jenis efikasi yang paling awal ketika konsep efikasi diperkenalkan. Saat itu Albert Bandura sebagai tokoh yang memperkenalkan konsep ini mengatakan bahwa efikasi mengajar guru merupakan jawaban guru ter- hadap pertanyaan yang muncul dalam dirinya terkait bagaimana mengatasi siswa yang kesulitan belajar. Misalnya pertanyaan " $D a$ patkah saya menangani siswa yang mengalami kesulitan?", "Berapa besar usaha yang harus dilakukan?", "Bagaimana tingkat kesulitan yang dialami siswa?" dan pertanyaan tentang kesulitan siswa lainnya (Henson, 2001). Jumlah guru yang masuk dalam karakteristik efikasi ini cukup besar (26 persen). Guru pada kelas ini merasa yakin mampu memperagakan apa yang dijelaskan oleh Sujarwo (2010) sebagai guru yang memberikan perhatian yang hangat dan suportif diyakini bisa memberi motivasi belajar siswa, memiliki empati dan memberikan umpan balik positif yang dapat membantu perkembangan belajar siswa secara signifikan.

Sementara itu guru yang masuk dalam Kelas-4 menunjukkan bahwa mereka memiliki keyakinan mampu merencanakan proses pembelajaran yang efektif akan tetapi masih belum memiliki keyakinan untuk mengimplementasikan dengan baik. Guru pada kelas ini meyakini telah memiliki penguasaan materi yang cukup baik dan disertai dengan kemampuan menggunakan variasi media peraga pembelajaran. Namun, sayangnya keyakinan tersebut tidak disertai dengan keyakinan untuk mampu mengelola kelas, mengembangkan instrumen evaluasi pembelajaran serta dan memberikan umpan balik.

Ada dua hal yang mempengaruhi munculnya guru dengan karakteristik kelas4. Pertama, dalam konteks praktis mereka sebenarnya mampu mengelola kelas dengan baik namun beberapa faktor menyebabkan penilaian menjadi rendah. Dari respons guru tersebut terhadap butir-butir di dalam alat ukur maka terlihat bahwa faktor tersebut adalah frekuensi mendapatkan evaluasi yang negatif, memiliki standar penilaian yang terlalu tinggi, dan memiliki kepercayaan diri yang rendah. Kedua, mereka memang benar-benar kurang yakin dengan kemampuannya. Guru dengan karakteristik seperti ini membutuhkan penguatan agar mereka memiliki kepercayaan diri untuk mampu mengelola kelas dengan baik. Cara yang bisa dilakukan adalah melibatkannya dalam proses pengambil- 
an keputusan mengenai pengelolaan kelas (Dodgshon, 2002) atau menambah jam mengajar di kelas bagi guru yang masih muda (Wilson \& Tan, 2004).

Adanya dua kelompok unik dalam hal efikasi guru mengajar menunjukkan bahwa tahapan proses mengajar di kelas dari persiapan, implementasi serta evaluasi merupakan dimensi yang terpisah. Rekomendasi yang dapat diberikan dari penelitian ini adalah peningkatan kompetensi guru hendaknya dilakukan secara komprehensif. Pelatihan-pelatihan tambahan yang diberikan kepada guru hendaknya dilakukan tidak hanya memusatkan pada penguasaan kurikulum atau pengembangan silabus. Guru juga membutuhkan pelatihan bagaimana mengelola kelas, berinteraksi secara hangat dengan siswa, mengembangkan instrumen evaluasi belajar dan memberikan umpan balik terhadap hasil belajar siswa. Sementara itu dari tiga dimensi yang dilibatkan dalam penelitian ini yaitu perencanaan, implementasi di kelas, dan evaluasi belajar siswa, dimensi ketiga yaitu penerapan proses evaluasi belajar siswa yang efektif menjadi catatan tersendiri. Tidak ada kelas unik dari hasil analisis kelas laten yang mendeteksi adanya guru yang yakin mampu menjalankan prosedur evaluasi belajar siswa dengan baik. Temuan tersebut menunjukkan bahwa guru masih membutuhkan peningkatan lebih lanjut dalam hal penyusunan alat ukur pendidikan yang baik dan sekaligus memberikan umpan balik kepada siswa mengenai hasil belajar mereka.

Hasil analisis yang melibatkan data demografi tidak menunjukkan hubungan antara karakteristik efikasi guru dalam mengajar dengan jenis kelamin, usia dan masa kerja. Hasil ini konsisten dengan penelitian-penelitian sebelumnya (Brown, 2009). Temuan tersebut menunjukkan bahwa keyakinan guru terhadap kemampuannya merupakan proses internal psikologis guru. Guru yang memiliki pengalaman mengajar yang cukup lama belum tentu yakin akan mengajar dengan baik. Adanya kebijakan baru, perubahan standar kompetensi, tuntutan masyarakat serta lingkungan sekolah tempat guru mengajar mendukung penilaian guru terhadap kemampuan yang dimilikinya. Oleh karena itu, berbagai upaya yang dilakukan untuk meningkatkan efikasi guru dalam mengajar baik melalui pelatihan atau program perlakuan tertentu diharapkan dilakukan pada semua guru.

Selain dua kelas karakteristik guru yang unik, ada dua kelas karakteristik efikasi guru dalam mengajar yang memberikan respons konsisten untuk semua indikator (Kelas-1 dan Kelas-2). Meskipun ada kemungkinan guru yang masuk ke dalam Kelas-1 (memiliki semua indikator efikasi mengajar) memberikan penilaian terlalu tinggi terhadap kemampuan mereka namun dalam konteks efikasi mengajar hal ini sangat diperlukan. Terlepas dari penilaian mereka berikan yang cenderung over estimasi namun sifat tersebut pada tataran tertentu dibutuhkan untuk mendukung performansi dalam mengajar. Penelitian menunjukkan bahwa guru yang memiliki tingkat efikasi mengajar yang tinggi terbuka terhadap inovasi-inovasi baru dalam bidang pendidikan (Zhenhong, Kejing, Xuqun, \& Huaixing, 2010) dan lebih antusias dalam mengajar (Jie-ying, 2011). Sebaliknya, catatan perlu diberi kepada Kelas-2 yang memuat guru yang merasa tidak yakin mampu melak-sanakan proses pembelajaran dengan baik.

\section{Simpulan}

Dalam teori pengukuran, konstruk atau atribut yang diukur dioperasionalisasikan menjadi dimensi-dimensi yang bersifat homogen. Penelitian ini menemukan bahwa dimensi dalam konstruk efikasi guru mengajar tidak bersifat homogen ketika diterapkan pada sampel. Ada guru yang dominan pada dimensi satu tetapi tidak dominan pada dimensi lainnya. Dari dua kelas unik yang diidentifikasi dari analisis didapatkan bahwa efikasi guru dapat dominan pada dimensi persiapan dan interaksi dengan siswa akan tetapi tidak dominan pada dimensi evaluasi dan pengukuran. Rekomendasi yang didapatkan adalah agar interpretasi skor yang didapatkan dari pengukuran efikasi guru mempertimbangkan guru dengan karakteris- 
tik unik tersebut. Di sisi lain, program-program pelatihan peningkatan efikasi maupun kompetensi guru dilakukan secara spesifik sesuai dengan karakteristik guru.

\section{Daftar Pustaka}

Ashton, P. T., Webb, R. B., \& Nancy, D. (1982). A Study of teachers sense of efficacy. Research Report. Washington, DC: University of Florida.

Ball, D. L. (1990). The mathematical understandings that prospective teachers bring to teacher education. The Elementary School Journal, 90(4), 449-466.

Bandura, A. (1977). Self-efficacy: toward a unifying theory of behavioral change. Psychol Rev, 84(2), 191-215.

Brown, B. E. P. (2009). Alabama high school special education teachers' efficacy beliefs in student engagement, instructional practices, and classroom management Dissertation, Alabama State University, Alabama

Buss, R. R. (2010). Efficacy for teaching elementary science and mathematics compared to other content. School Science and Mathematics, 110(6), 290 297.

Dellinger, A. B., Bobbett, J. J., Olivier, D. F., \& Ellett, C.D. (2008). Measuring teachers' self-efficacy beliefs: development and use of the tebs-self. Teaching and Teacher Education, 24(3), 751-766.

Dodgshon, R. (2002). The age of the clans: the bighlands from somerled to the clearances. Edinburgh: Birlinn.

Eddy, C., \& Easton-Brooks, D. (2011). Teacher efficacy as a multigroup model using latent class analysis. Education Research International, 2011, 1 7.

Flores, B., \& Clark, E. R. (2004). A critical examination of normalistas selfconceptualization and teacher- efficacy. Hispanic Journal of Behavioral Sciences, 26, 230.

Franklin, V. L. (1989). Teacher efficacy and selected organizational climate variables in urban and suburban school settings.

Dissertation, University of Bridgeport, Connecticut.

Gibson, S., \& Dembo, M. H. (1984). Teacher efficacy: a construct validation. Journal of Educational Psychology, 76, 503-511.

Henson, R. K. (2001). Teacher self-efficacy: substantive implications and measurement dilemmas. In The annual meeting of the Educational Research Exchange, Texas.

Hofstee, W. K. B. (2003). Structures of personality traits. San Francisco, CA: John Wiley \& Sons, Inc.

Hoy, A. W. (2000). Changes in teacher efficacy during the early years of teaching. In The Annual Meeting of the American Educational Research Association, New Orleans.

Jerald, C. D. (2007). Believing and achieving. Washington, DC: Center for Comprehensive School Reform and Improvement.

Jie-ying, Y. (2011). Teacher efficacy and college english teaching. Asia-Pacific Science and Culture Journal, 1(1), 34-42.

Leyser, Y. (2002). Choices of instructional practices and efficacy beliefs of israeli general and special educators: a crosscultural research initiative. Teacher Education and Special Education: The Journal of the Teacher Education Division of the Council for Exceptional Children, 25(2), 154-167.

Magogwe, J. M. (2006). The relationship between proficiency and self-efficacy beliefs of the University of Botswana students learning ESL. Marang, 16, 121-131. 
Matthews, G., Deary, I. J., \& Whiteman, M. C. (2003). Personality traits. New York: Cambridge University Press

Muthen, L. K., \& Muthen, B. O. (2005). Mplus: Statistical Analysis with Latent Variables: User's Guide. Los Angeles, CA.: Muthen \& Muthen.

Newman, E. J. (1999). In the trenches: increasing competency of teachers-in training by having them conduct individualized interventions. Journal of Instructional Psychology, 26(1), 36.

Nylund, K. L., Asparouhov, T., \& Muthén, B.O. (2007). Deciding on the number of classes in latent class analysis and growth mixture modeling: A monte carlo simulation study. Structural Equation Modeling: A Multidisciplinary Journal, 14(4), 535-569.

Pang, V. O. (2009). The beliefs of successful Asian American Pacific Islander teachers: how culture is embedded in their teaching. Asian Americans \& Pacific Islanders Policy, Practice and Community, 7(1), 55-82.

Ryan, H. D. (2007). An examination of the relationship between teacher efficacy and teachers' perceptions of their principals' leadership behaviors. University of North Texas, Denton, Texas.
Sujarwo. (2010). Peranan guru dalam pemberdayaan siswa. Dinamika Pendidikan, 17(1), 1-10.

Tschannen-Moran, M., \& Hoy, A. W. (2001). Teacher efficacy: capturing an elusive construct. Teaching and Teacher Education, 17(783-805).

Valentini, P., Di Battista, T., \& Antonio Gattone, S. (2011). Heterogeneity measures in customer satisfaction analysis. Journal of Classification, 28(1), 38-52.

Wilson, P., \& Tan, G. C. I. (2004). Singapore teachers' personal and general efficacy for teaching primary social studies. International research in geographical and environmental education, 13, 209-222.

Woolfolk, A. E., Rosoff, B., \& Hoy, W. K. (1990). Teachers' sense of efficacy and beliefs about managing students. Teaching and Teacher Education, 6, 137 148.

Zhenhong, W., Kejing, W., Xuqun, Y., \& Huaixing, D. (2010). Effects of teacher efficacy,work motivation, and mood on teaching innovation. Psychological Science, 5. 